\title{
Guidance Model for Promoting Self-Directed Career Decision-Making by Secondary School Students
}

\author{
Linda Briska ${ }^{1}$ Mg. ed.; Vija Dislere ${ }^{2}$ Dr. paed. \\ Aizkraukle Regional Secondary School, Latvia ${ }^{1}$ \\ Latvia University of Life Sciences and Technologies, Latvia ${ }^{2}$ \\ linda.brishka@inbox.lv ${ }^{1}$; vija.dislere@1lu.lv²
}

\begin{abstract}
The present research focuses on a problem for secondary school students - their inability to make crucial decisions on their future profession as well as to understand themselves, their interests, abilities and needs. Many secondary school graduates do not know what profession to choose. The aim of the research is to develop a guidance model for promoting self-directed career decision-making by secondary school students as well as to approbate the model and perform an expert evaluation of the model. The approbation of the model was done at two secondary schools in Latvia's regions. Thirty-two school pupils were involved, of which 16 were students from grade 12 from each school. Individuals investigate own interests, abilities and talents, sets learning and career goals, plans own work and does reflection on their own initiative in self-directed learning. During this process, students build up their abilities and their need to self-guide increases; their personality grows, and the students become more active and assume a greater responsibility for their decisions related to their learning and careers. The students, involved in the experimental approbation of the guidance model for promoting self-directed career decision-making, acquired a new knowledge, identified their abilities, interests and values, became self-confident and got a clear vision of their goals; their internal motivation to make a responsible and thought-out career decision increased. The guidance model is intended for career counsellors, pedagogues-career counsellors and class teachers working with secondary school students.
\end{abstract}

Keywords: self-directed learning, career decision-making, model, career counselling, school education.

\section{Introduction}

The authors of the research, working in pedagogy in the field of interest education for more than 20 years, often faced a problem for secondary school students to make a crucial decision regarding their future profession as well as to understand themselves, their interests, abilities and needs. During the last secondary school semester or even the last month of studies, very many secondary school students did not know what speciality to choose for studies or work. Regarding K. Balcere (2013) studies only less than $2 \%$ of them used career counsellor advice to make a good career decision. At present, there is a situation at schools that individual consultations are almost unavailable for every student because a career counsellor is available only for a few hours or days a week. A career counsellor is only available at group events and during lessons, during career week, or during parents' meetings. One career counsellor per six or seven hundred students is unable to provide sufficient assistance, to get into details regarding every student's progress towards making a career decision. Therefore, the authors seek for ways to provide support for any school student in making a career decision, so that the student can do it through selfguidance. Being aware of this problem, caused a desire and motivation for the authors to explore opportunities for students to cope with a problem to make a career decision and make a professional choice, investing their own time and efforts and using a career counsellor's guidance from a distance.

The aim of the research is to develop a Guidance model for promoting self-directed career decisionmaking for secondary school students (hereafter referred to as Guidance Model) as well as to approbate the model and perform an expert evaluation of the model.

\section{Methodology}

The research questions included: to find out theoretically what self-directed learning is and how to encourage it for secondary school students; what kind of guidance model is necessary for a secondary school student's self-directed career decision-making.

Methods of the research included: theoretical study, analysis of scientific literature and reflection of authors' personal experience and a Friedman's test are used. 
The Guidance Model is developed on the basis of theoretical studies on self-directed learning and theoretical models and approaches in decision-making, as well as based on the authors' experience of working with youngsters.

The Guidance Model was developed at the Institute of Education and Home Economics, Latvia University of Life Sciences and Technologies within the master study programme Career Counsellor. The approbation of the model was done at two secondary schools in Latvia's regions. Thirty-two school pupils were involved, of which 16 were students from grade 12 from each school. The students were asked to use the guidance model for making a career decision, using the model's ten steps to complete all tasks and in parallel to use a career counsellor's help via e-mail or Skype, as well as, if necessary, face-to-face consultations. The guidance model was evaluated by five competent experts and their ratings were subjected to statistical analysis using a Friedman's test. The experts were asked to evaluate the Guidance Model by examining it against the following seven criteria: (K1) Self-directed learning is applicable for secondary school students. (K2) Decision-making models (so far developed by other authors), which are included in the Guidance Model, contain useful information for secondary school students. (K3) Factors influencing career decision-making correspond to secondary school students' age group. (K4) Decision-making difficulties, mentioned in Guidance Model, are adequate for secondary school students. (K5) Career counsellor' guidance types are enough to achieve the purpose of the Guidance Model. (K6) 10-steps self-directed actions are enough to achieve the purpose of the Guidance Model. (K7) The Guidance Model as a whole is good enough to promote the skills to make independent, responsible and informed career decisions for secondary school students. The experts were asked to evaluate the given criteria in five-step scale: strongly agree (5), partially agree (4) difficult to judge (3), partially disagree (2) disagree (1).

\section{Theoretical Framework for Self-Directed Learning}

Various authors give different interpretations for the term self-directed learning. M.S. Knowles (1975) points out that self-directed learning is a process in which individuals take the initiative without the help of others in diagnosing their learning needs, identifying and formulating their learning goals, identifying resources for their learning, choosing and implementing a learning strategy and evaluating learning outcomes. M. Gibbons (2002) believes that self-directed learning involves building up one's knowledge, skills and achievements or contributing to personality growth, which is achieved through one's own efforts or activities by means of any technique, under any circumstances and at any time. Latvian scientist D. Liegeniece (2002) has called self-directed learning a form of studies in which adults take responsibility for planning their work, applying their knowledge and assessing their work.

Historically, the first attempts to define self-directed learning were dated about 170 years back. In that period in America G.L. Craik (1872) referred to and researched self-education attempts done by various individuals. In Great Britain, S. Smiles (1859) published a book entitled Self-help, in which he popularised his concept of personality development. As time passed, such research studies intensified, while the major research contributions were made by C.O. Houle (1961). The scientist interviewed 22 individuals and classified them into categories based on the reasons why they educated themselves. His three classifications were goal-oriented, activity-oriented, and learning-oriented. C.O. Houle's work was continued by his student, a Canadian researcher, A. Tough (1979). In his dissertation, he analysed self-directed learning activities that were summarised in a book entitled Adult Learning Projects. At the same time, M.S. Knowles (1975) published a work entitled Self-directed Learning that gave various definitions and assumptions related to extensive research, for example: self-directed learning assumes that as an individual grows, the individual's abilities and need to direct him/herself increases; an individual's experience is a good learning resource; an individual learns what is necessary to achieve his/her life goals. R. Hiemstra (1994) considers that during self-directed learning, motivation forms from internal stimuli such as the need for self-respect, achievements and curiosity.

H.B. Long (Long, Stubblefield, 1994) with his colleagues established an annual International Symposium on Self-Directed Learning. The Symposia have spawned many publications, research projects and theory building efforts by researchers throughout the world (Hiemstra, 1994). As the role of self-directed learning increased, the diverse aspects of it have been researched by R.G. Brockett and R. Hiemstra (Brockett, Hiemstra,1991), R.S. Caffarella and J.M. O'Donnell (Caffarella, O’Donnell, 1987), P.C. Candy (1991), S. Merriam and R. Caffarella (Merriam, Caffarella, 1991) and S.D. Brookfield (Brookfield,1985,1994). 
The following things are known about self-directed learning by R. Hiemstra (1994): individual learners can become empowered to take increasingly more responsibility for various decisions associated with the learning endeavour; self-direction is best viewed as a characteristic that exists to some degree in every person and learning situation; self-direction does not mean all learning will take place in isolation from others; a self-directed learning participant is able to transform a variety of situations affecting both their knowledge and studying skills; self-directed study can involve various activities and resources, such as self-guided reading, participation in study groups, internships, electronic dialogues, and reflective writing activities; effective roles for teachers in self-directed learning are possible, such as dialogue with learners, providing resources, evaluating outcomes, and promoting critical thinking.

\section{Promoting Self-Directed Learning by Secondary School Students}

Self-direction in learning can be learned and can be taught. J.A. Regan (2003) recommends to find out what motivates students to turn to self-directed learning. Students need to be motivated and encouraged to discover their own motivations.

The key responsibility of a career counsellor is to help students to develop their self-directed learning process and their independent decision-making process. In the opinion of K. Ramnarayan and S. Hande (Ramnarayan, Hande, 2005) the students who are accustomed to fully relying on the teacher's complete management might have problems to get used to their responsibility in the ongoing learning process. Successful self-directed learning requires that students have certain characteristics and behaviour. H. Okabayashi and E.P. Torrance (Okabayashi, Torrance, 1984) defined corresponding abilities for the characteristics: ability to be aware of the most significant and important information in an assignment; ability to find sources of information; ability to think independently and follow instructions and rules; ability to be aware of and accept responsibility for learning; ability to take the initiative in starting an assignment. Students who possess such abilities have self-awareness. According to T. Smith (2017) they understand how they learn and are aware of a learning outcome they want to achieve. I. Soika (2017) emphasize the importance of dialogue and describe the developmental stages which prevailing in dialogue of student's career guidance in secondary education. After examining the promotion of selfdirected learning, K. Brouse (2007) recommended pedagogues to encourage self-direction in students through: giving assignments to the students, in which they examine things they are interested in; encouraging the students to express their opinions; allowing the students to work at their own pace; viewing things from different perspectives; doing reflection on their learning pace and write down their learning outcomes; giving multiple choice assignments to the students.

In Canada, researchers from the University of Waterloo have developed a four-step method for selfdirected learning (Self-Directed Learning..., 2016): 1) Readiness for learning. The readiness is indicated by the facts that the student is autonomous, self-organised, disciplined, ready to communicate effectively, able to engage in a constructive assessment and reflection, and the student possesses certain skills in managing and planning the time and resources and in analysing and examining the problem. 2) Setting goals. Researchers recommend that the student discuss the goal with a career counsellor. At the same time, the teacher and student jointly decide on the activities to be done, the deadline, the resources needed for every activity and the need for meetings. 3) Engagement in learning. The student has to be aware of him/herself as a participant in the self-directed learning process. The student has to understand his/her needs as a self-directed student. The student has to answer the following questions: What are my needs and what learning approach is necessary? The student has to become a motivator for him/herself. 4) Evaluating learning outcomes. The student has to be able to engage in self-reflection and assess the learning outcome. In case of need, the student has to consult a career counsellor and take the advice. To assess his/her own work, the student has to ask him/herself the following questions: Am I able to freely use the information acquired? How do I know that I have learnt what I needed? At what moment do I need self-reflection and when do I need to visit a career counsellor for advice?

\section{Theoretical Models and Approaches in Decision-Making}

J.A. Athanasou and R. Esbroeck (Athanasou, Esbroeck, 2008) distinguish several kinds of decision-making models: normative models define what individuals should do to make a decision based on theories; descriptive models examine the ways individuals make a decision in real contexts, as well as the difference 
between the ideal, normative decision-making process and real-life situations; prescriptive models prescribe what individuals have to do, taking into consideration what the individuals can do to make a decision.

For making a career decision, L.K. Mitchell and J.D. Krumboltz (Mitchell, Krumboltz, 1996) suggest a seven-stage DECIDES model (define, establish, clarify, identify, discover, eliminate, start), which is one of the normative models and it involves the following steps: define the problem, be aware of the need for making a decision; establish an action plan, correct the decision; clarify values, examine self-observations and worldview generalisations; identify, seek for alternatives; collect information, discover probable outcomes; assess the information, eliminate alternatives; start action: plan and perform the six above-mentioned decision-making steps (Gikopoulou, 2008).

At the Career Centre of the University of Florida, a group of researchers developed the Cognitive Information Processing (CIP) Approach by combining theory, practice and research; the approach is one of the descriptive models. The approach developed by J.P. Samson, R.C. Reardon, G.V. Peterson and J.G. Lenz (Sampson et al., 2004) is based on a three-level pyramid; self-cognition and the awareness of professions is placed at the lowest level; decision-making skills are at the second level (that includes five cognitive information processing skills, known as the CASVE cycle - communication, analysis, synthesis, valuing and execution). Execution is placed at the top level of the pyramid, which involves metacognition - thinking about our thinking. This is the stage for verifying and evaluating the thinking process, in which one can ask the following questions: How does it function? How should I improve it? What should be enhanced?"

One of the prescriptive models is the PIC model (pre-screening, in-depth exploration, choice); its authors are I. Gati and I. Asher (Gati, Asher, 2001). The scientists made the decision-making process easier by dividing it into three steps: 1 ) pre-screening - its purpose is to select potential career alternatives based on personal priorities; this results in up to seven potential options; 2 ) in-depth exploration - it aims at choosing a few options (3-4) being the most appropriate for the client from among the options selected at the previous stage; 3 ) choice - the purpose is to choose the most appropriate options, which is based on a detailed comparison of the most appropriate options. The authors preferred using the ideas of the mentioned models in developing their guidance model for promoting self-directed career decisionmaking by secondary school students. The author chose these models to use for creating the new Guidance Model, because all of them include elements such as access to information, self-exploration, overcoming obstacles, priority setting and the examination of several options.

\section{Decision-Making Problems}

Individuals possess different abilities to make a career decision. A number of authors have sought theoretical explanations of why individuals have problems making a career decision. The reasons mentioned by them are as follows: D.E. Super's (1963) vocational maturity, J.O. Crites' (1978) career maturity, D.E. Super's (1953) one's self-image, D.E. Super's and M.L. Savickas' adaptability (Super, 1983, Savickas, 1996, 2005), A. Bandura's (1989) self-efficacy, J.L. Holland's vocational identity (Holland, 1985, 1994), R.W. Lent's and G. Hackett's decision-making and self-efficacy (Lent, Hackett, 1987), J.D Krumboltz's (1983) beliefs, and dysfunctional career thinking of J.P. Sampson, R.C. Reardon, G.W. Peterson and J.G. Lenz (Sampson et al., 2004). G. Ford (2002) mentions self-esteem and satisfaction with oneself as the key abilities for making a career decision. Raising selfesteem in the counselling process could build up the ability to make a decision. Some clients express their doubts about being aware of their strengths and weaknesses.

T. Nakao (Nakao, Mitsumoto, Naswiva, 2010), a psychology and pedagogy scientist, has proved in his research that getting familiarised with oneself reduces the problem of making a choice. In situations where an individual has to choose from among similar options, the individual uses his/her knowledge of him/herself to facilitate decision-making.

By the opinion of G.S. Niles and J. Harris-Bowlsbey (Niles, Harris- Bowlsbey, 2002), many youths lack the ability to make a career decision owing to the fact they lack career maturity. To make a better career choice, the youth have to: develop a positive attitude to career examination and planning, learn how to acquire information about themselves and professional opportunities and learn how to make a career decision. 
The task of a career counsellor is not to guide a client towards the right decision but to help the client to cope with the problem to make a decision. According to I. Gati and N. Levin (Gati, Levin, 2014). Several aspects complicate making a career decision, for example: too large number of options to choose from; factors to be taken into account when choosing a profession, e.g. work conditions, family circumstances, the duration or place of studies; uncertainty about the profession and oneself and if a compromise is necessary in career decisions; social barriers - imaginary or real - that influence a decision; most clients are afraid of serious and important decisions and therefore worry about making a "wrong" decision.

Summarizing several researcher's thoughts about the career decision-making difficulties it can be concluded that a career counsellor has to provide support for young people in vocational choices, encouraging them to explore themselves, their abilities, skills, interests, traits; a career counsellor has to activate the cognitive training and to build up the youth's resources with regard to their individually preferred professions. It is necessary to ascertain young people's social environment, the barriers and influencing factors which could create internal conflict in decision making or cause pressure from outside. The youth have to be encouraged to take responsibility for their decisions as well as given references about information sources to get familiarised with the profession.

\section{Results and Discussion}

\section{Development of the Guidance Model for Promoting Self-Directed Career Decision-Making}

The guidance model was developed with the purpose of facilitating a self-directed career decision by secondary school students. The Guidance Model for promoting self-directed career decision-making (Figure 1) was developed based on theoretical knowledge about self-directed learning, problems to make a decision and career counselling specifics for the secondary school students, as well as on an analysis of the data of main problems and difficulties to make a decision obtained at the first stage of the authors' research. Based on the authors' experience in previous studies the main problems were associated with the lack of information, the existence of several alternatives, no awareness of one's interests, abilities and values as well as the influence of one's socio-economic conditions on making a decision. The Guidance Model and its methodology (a 10-step method) focus on self-guidance through all the problematic matters, allowing students to deal with the themes which present the biggest problems.

\section{Expert Evaluation of the Guidance Model}

Experts were asked to evaluate the guidance model's significance and usefulness for making a self-guided career decision for secondary school students. The authors wished to determine whether the model and its methodology (the 10-step method) were useful for work with secondary school students and whether the model facilitated the students' independent career decision-making. Five experts were involved in evaluating the guidance model; the experts had substantial experience in the fields related to career counselling, pedagogy or psychology.

The experts were e-mailed a description of the Guidance Model, as well as the methodology including worksheets of the 10-step method.

Table 1 shows the results of experts' assessment as descriptive statistics. The experts are marked by the letters A, B, C, D, E. The criteria are marked with the letter K1...K7. Numbers from 1 to 5 points show the evaluation of each expert from strongly agree (5) to disagree (1).

As it can be seen from the sum of all responses, all experts fully agree that the self-directed learning is applicable for secondary school students (K1), as well as, that the decision-making models (previously developed by other authors), which are included in the Guidance Model, contain useful information for secondary school students. Also evaluating the Guidance Model as a whole as effective tools for promoting the skills to make independent, responsible and informed career decisions for secondary school students, experts agree with the statement (K7). On the issue of factors influencing career decision-making corresponding to secondary school students' age group one expert partially agreed with the statement, but four experts completely agree (K3).

Most of experts are completely agreed that decision-making difficulties, mentioned in Guidance Model, are adequate for secondary school students (K4), one expert - partially agreed and one expert acknowledged that it is difficult to judge. 


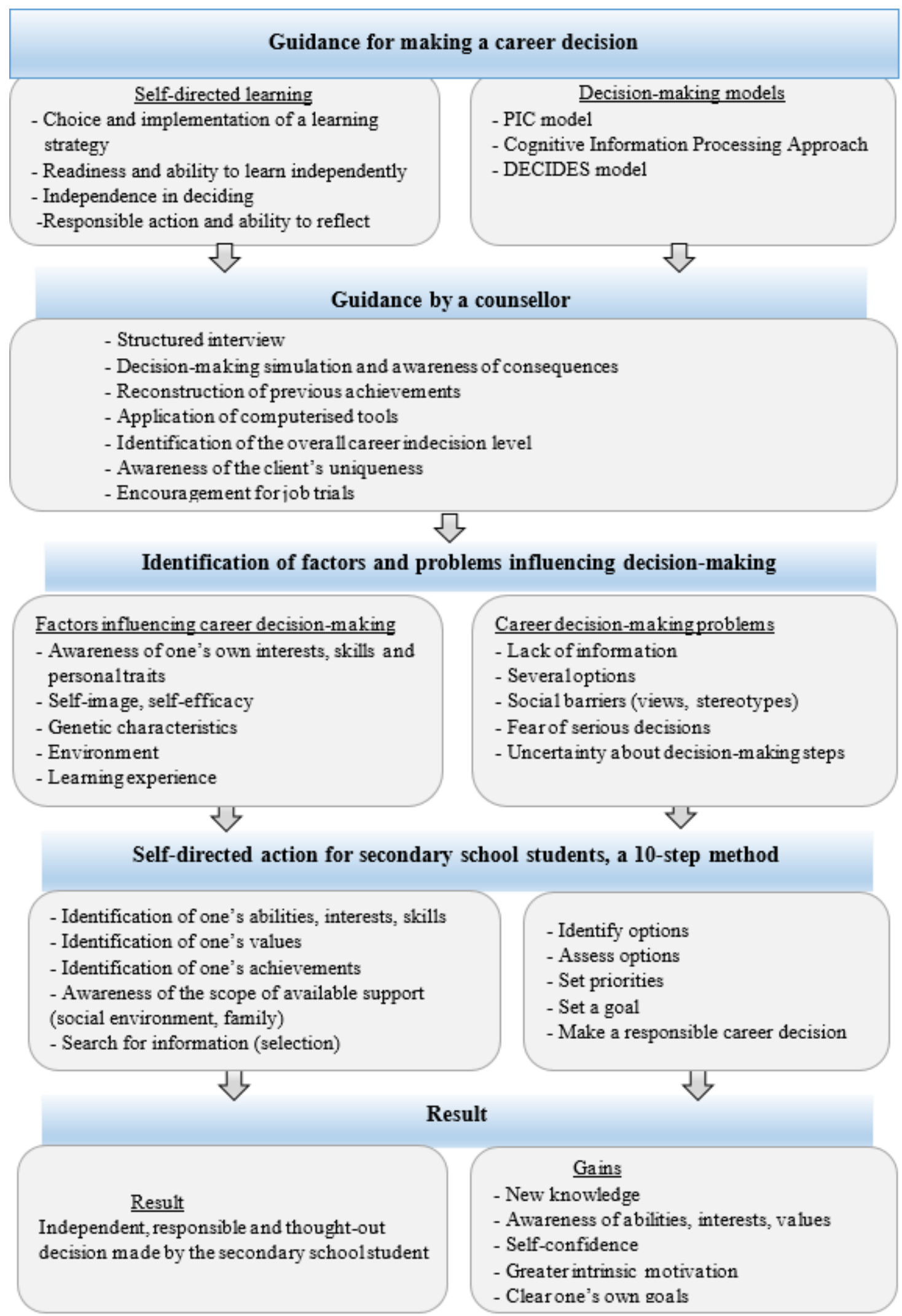

Figure 1. Guidance model for promoting self-directed career decision-making by secondary school students. 
Data obtained during expert evaluation

Table 1

\begin{tabular}{|c|c|c|c|c|c|c|c|c|c|c|c|}
\hline Experts & $\mathbf{A}$ & B & $\mathrm{C}$ & D & $\mathbf{E}$ & $\sum$ & Min & Max & $\mathbf{A}$ & Me & Mo \\
\hline K1 & 5 & 5 & 5 & 5 & 5 & 5 & 5 & 5 & 0 & 5 & 5 \\
\hline K2 & 5 & 5 & 5 & 5 & 5 & 5 & 5 & 5 & 0 & 5 & 5 \\
\hline K3 & 5 & 4 & 5 & 5 & 5 & 4 & 4 & 5 & 1 & 5 & 5 \\
\hline K4 & 3 & 4 & 5 & 5 & 5 & 2 & 3 & 5 & 2 & 5 & 5 \\
\hline K5 & 4 & 5 & 5 & 5 & 4 & 3 & 4 & 5 & 1 & 5 & 5 \\
\hline K6 & 3 & 5 & 4 & 5 & 4 & 1 & 3 & 5 & 2 & 4 & 4,5 \\
\hline K7 & 5 & 5 & 5 & 5 & 5 & 5 & 5 & 5 & 0 & 5 & 5 \\
\hline$\sum$ & 30 & 33 & 4 & 5 & 3 & & & & & & \\
\hline Min & 3 & 4 & 4 & 5 & 4 & & & & & & \\
\hline Max & 5 & 5 & 5 & 5 & 5 & & & & & & \\
\hline A & 2 & 1 & 1 & 0 & 1 & & & & & & \\
\hline $\mathrm{Me}$ & 5 & 5 & 5 & 5 & 5 & & & & & & \\
\hline Mo & 5 & 5 & 5 & 5 & 5 & & & & & & \\
\hline
\end{tabular}

Where:
Me - Median;
$\Sigma$ - the sum of all the elements;
Mo - Moda;
Min - the minimum value;
A - amplitude variation;
Max - the maximum value.

Also, career counsellor' ways of support in the Guidance Model are evaluated with the maximum of value of the three experts and two experts partly agree with this statement (K5). There is not complete consensus of the expert opinions about the evaluation whether secondary school students self-directed actions using the 10-steps method are enough to achieve the purpose of the Guidance Model (K6), two of the experts fully agree with this statement, two experts - partly agrees, but one expert believes that it is difficult to judge.

The expert evaluation's data were processed using the SPSS program and Friedman's test. Friedman's test is a nonparametric test that compares several paired groups. The test is used for interval and ordinal scale data. The data obtained were as follows as shown in Table 2.

Table 2

\begin{tabular}{|l|r|}
\hline Freidman's test results \\
\hline A & Average rank \\
\hline B & 2.29 \\
\hline C & 2.93 \\
\hline D & 3.29 \\
\hline E & 3.57 \\
\hline
\end{tabular}

\begin{tabular}{|l|r|}
\hline Test Statistics(a) & 7 \\
\hline Number (N) & 6.169 \\
\hline Chi-Square & 4 \\
\hline Degrees of freedom (Df) & 0.187 \\
\hline P-value (Asymp. Sig.) & \\
\hline
\end{tabular}

\section{The experts gave their comments and suggestions.}

Expert $\mathrm{C}$ suggested that the mathematical decision-making method may be combined with the self-guided decision-making steps, i.e., students mathematically evaluate the factors important for themselves for various alternatives (e.g. for the choice among several professions or educational institutions). The authors agree with this suggestion and consider it useful for improving the 10-step method.

Expert $\mathrm{C}$ suggested that the 10-step method may also be used at primary school, as each step reveals correct solutions in case a pupil does not know the answer. At secondary school this method may be used for individual assignments, while at primary school the assignments may be done by pupils together with a class teacher or a counsellor.

The authors fully agree with this suggestion, as author L. Briska has informally tested it on grade nine students and has concluded that the method may be used, but only in a different form - the teacher, parents or a career counsellor have to be more engaged. 
Expert E gave additional advice on additional factors that could influence students' career decisionmaking including their health condition and perception specifics and prior learning. Expert E mentioned psychological support, guidance in planning activities and determining professional appropriateness as additional kinds of career guidance by a counsellor. However, if the model is implemented, the experts also mentioned the build-up of judgement abilities, the awareness of lack of skills, students' choice of growth and their active and positive life position as the gains for the students.

Before and after the experimental testing the Guidance Model survey was carried out about the level of difficulty of career decision-making for school students involved in the research. Researchers compared the level of decision-making difficulty before and after the approbation of the Guidance Model. It can be concluded that the decision making involved in this exercise supported students' improvement in decision making skills overall. An equal number of respondents have noted the decisionmaking level as difficult. Overall, analysing respondents' answers it can be seen that, when assessing the decisionmaking difficulties before and after approbation of the Guidance Model, a positive trend in the decision-making level of difficulty is observed (Figure 2).

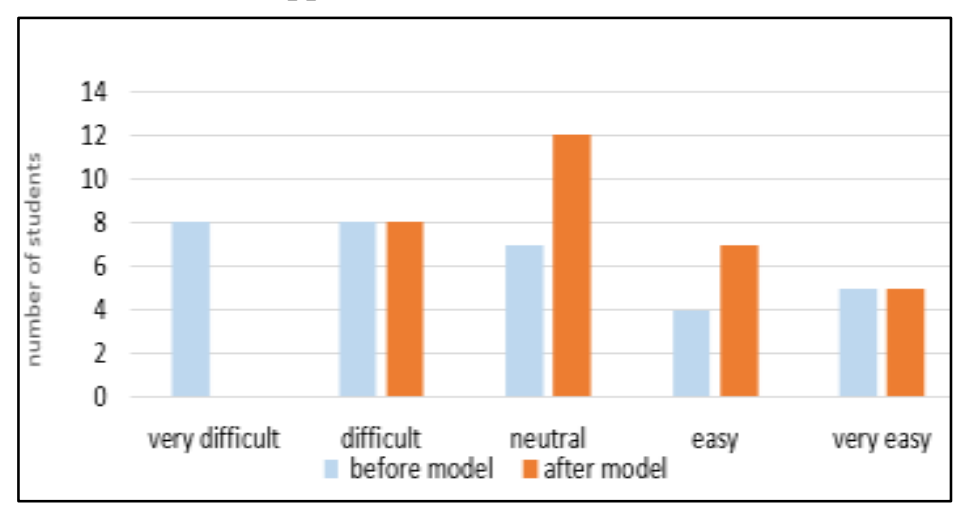

Figure 2. The level of difficulty of career decisionmaking for school students before and after the Guidance Model' approbation.

Model improves the ability to make a career decision and it makes the decision-making process easier for high school students. After using the 10-step method, the attitudes towards decision-making have become more positive and the decision-making difficulties are lessened. Using the Guidance Model, it is possible to improve the self-directed decision-making skills, overcoming difficulties in the decision-making related to the lack of information, unawareness of their interests, abilities, values and profession. Secondary school pupils need support and specific action plans for selfdirected action to be more effective for them. The 10-step method is suitable for students who want to be independent in their decisions and do not want an individual face-to-face meeting with a career counsellor, but they prefer virtual consultations. For self-directed decision-making to be more effective, it is advisable to apply the 10-step method to the specific study subject, thus making it easier to set deadlines for tasks and in addition motivating students to function better. To guide school students to self-directed learning it is important to respect the need for a positive, motivating learning environment and atmosphere, which prepares students to engage in self-directed activities.

\section{Conclusions}

After summarising the findings of several authors, it can be concluded that self-directed learning is a process_where individuals ascertain their interests, abilities and talents, set their learning and career goals, choose and implement a learning strategy, plan their work and do reflection on their own initiative. In this process, students build up their abilities and their need for self-directed learning increases; their personality grows, and the students become more active and assume a greater responsibility for their decisions related to their learning and careers.

Based on the views of various authors, successful decision-making involves: implementing self-directed learning, seeking for associations between the personal traits of students themselves (their interests, needs, ego-conception, uniqueness) and the specifics of the profession chosen, looking for and assessing alternatives and acting regardless of the hindering circumstances.

The Guidance model for promoting self-guided career decision-making by secondary school students is a helpful tool for students in their self-directed learning and can assist them to make an independent and deliberate career decision. Students liked using the model and they successfully used it. Judging by the respondents' answers on the questionnaire it can be concluded that, assessing the decision-making difficulties before and after approbation of the Guidance Model, a positive trend in the decision-making level of students was observed. According to the author's observations after the experimental testing of 
the Guidance Model, working on the issues and themes causing decision-making problems for a particular individual, a lot of skills were improved for secondary school students including the individual's information search skills, comprehension of the decision-making steps, alternative search skills. The secondary school students, involved in the experimental approbation of the Guidance Model, made independent and deliberate career decisions. The authors observed that they learnt a new knowledge, acquired abilities, became aware of their interests and values, became self-confident, their goals became clear and their internal motivation increased. The model is intended for career counsellors, pedagogues-career counsellors and class teachers in their work with secondary school students.

After analysing the experts' ratings of the model, it can be concluded that the model was positively rated.

\section{Bibliography}

1. Athanasou J.A., Esbroeck R. (Eds.). (2008). International Handbook of Career Guidance. Netherlands: Springer Science, Bussines Media B.V.

2. Bandura A. (1989). Human Agency in Social Cognitive Theory. American Psychologist, 44(9), $1175-1184$.

3. Balcere K. (2013). Jauniesi Latvija neapzinas vajadzibu karjeras izveli veikt merktiecīgi. (Youth in Latvia are Unaware of the Need to Make a Career Choice Purposefully). Riga: VIAA. Retrieved from http://viaa.gov.lv/lat/info medijiem/?text id=20886 (in Latvian)

4. Brockett R.G., Hiemstra R. (1991). Self-Direction in Adult Learning: Perspectives on Theory, Research and Practice. London: Routledge.

5. Brookfield S.D. (1994). Self-Directed Learning. Adult and Community Education Unit 2: Approaching Adult Education. London: YMCA George Williams College.

6. Brookfield S.D. (1985). Self-Directed Learning: A Conceptual and Methodological Exploration. Studies in the Education of Adults, 17(1), 19-32.

7. Brouse C. (2007). Promoting Self-directed Learning in Three Online Health Promotion and Wellness Courses. Journal of Authentic Learning, 4(1), 25-33. Retrieved from http://citeseerx.ist.psu.edu/viewdoc/download?doi=10.1.1.424.3792\&rep=rep1\&type=pdf

8. Caffarella R.S., O’Donnell J.M. (1987). Self-Directed Adult Learning: A Critical Paradigm Revisited. Adult Education Quarterly, 37, 199 - 211.

9. Candy P.C. (1991). Self-Direction for Lifelong Learning: A Comprehensive Guide to Theory and Practice. San Francisco, CA: Jossey-Bass.

10. Craik G.L. (1872). Pursuit of Knowledge Under Difficulties. London: Bell and Daldy. Retrieved from https://archive.org/details/cu31924031240702

11. Crites J.O. (1978). Career Maturity Inventory: Theory and Research Handbook. (2nd ed.). Monterey, CA: McGraw-Hill.

12. Ford G. (2002). The Connexions Strategy and All-Age Guidance. Derby: Centre for Guidance Studies.

13. Gati I., Asher I. (2001). The PIC Model for Career Decision Making: Pre-Screening, In-Depth Exploration and Choice. In F.T.L. Leong, A. Barak (Eds.), Contemporary Models in Vocational Psychology. Mahwah, NJ: Erlbaum, 7-54.

14. Gati I., Levin N. (2014). Counselling for Career Decision-Making Difficulties: Measures and Methods. The Career Development Quarterly, 62, 98-113.

15. Gibbons M. (2002). The Self-Directed Learning Handbook: Challenging Adolescent Students to Excel. San Francisco, CA: Jossey-Bass.

16. Gikopoulou N. (Ed.). (2008). Report on Effective Career Guidance. Career Guide, 25.

17. Hiemstra R. (1994). Self-Directed Learning. In T. Husen, T.N. Postlethwaite (Eds.), The International Encyclopedia of Education. ( $2^{\text {nd }}$ ed.). Oxford: Pergamon Press. Retrieved from http://ccnmtl.columbia.edu/projects/pl3p/Self-Directed\%20Learning.pdf

18. Holland J.L. (1985). Making Vocational Choices: A Theory of Vocational Personalities and Work Environments. Englewood Cliffs, NJ: Prentice Hall.

19. Holland J.L. (1994). Separate but Unequal is Better. In M.L. Savickas, R.L. Lent (Eds.), Convergence in Career Development Theories. Palo Alto, California: CPP Books, 45-51.

20. Houle C.O. (1961). The Inquiring Mind. Madison, Wisconsin: The University of Wisconsin Press.

21. Knowles M.S. (1975). Self-Directed Learning: A Guide for Learners and Teachers. Englewood Cliffs, New Jersey: Prentice Hall/Cambridge. 
22. Krumboltz J.D. (1983). Private Rules in Career Decision Making. Special Publication Series, 38. Columbus, OH: The National Centre for Research in Vocational Education, 12-19.

23. Lent R.W., Hackett G. (1987). Career Self-Efficacy: Empirical Status and Future Directions. Journal of Vocational Behaviour, 30, 347-382.

24. Liegeniece D. (2002). Ievads androgogija (Introduction in Andragogy). Riga: RaKa. (in Latvian)

25. Long H.B., Stubblefield C.H. (1994). Childhood Experiences as Origins of Self-Directed Learning Readiness. In H. B. Long (Ed.), New Ideas about Self-Directed Learning. Norman, OK: Oklahoma Centre for Continuing Professional and Higher Education of the University of Oklahoma, 15-22.

26. Merriam S., Caffarella R. (1991). Learning in Adulthood: A Comprehensive Guide. San Francisco: Jossey-Bass.

27. Mitchell L.K., Krumboltz J.D. (1996). Krumboltz's Learning Theory of Career Choice and Counseling. In D. Brown, L. Brooks (Eds.), Career Choice and Development. ( $3^{\text {rd }}$ ed.). San Francisco, California: Jossey Bass, 233-280.

28. Nakao T., Mitsumoto M., Naswiva M. (2010). Self-Knowledge Reduces Conflict by Biasing One of Plural Possible Answers. Personality and Social Psychology Bulletin, 36, 455-469.

29. Niles G.S., Harris-Bowlsbey J. (2002). Career Development Interventions in the $21^{\text {st }}$ Century. New Jersey: Pearson Education.

30. Okabayashi H., Torrance E.P. (1984). Role of Style of Learning and Thinking and Self-Directed Learning Readiness in the Achievement of Gifted Students. Journal of Learning Disabilities, 17, 104-107.

31. Ramnarayan K., Hande S. (2005). Thoughts on Self-Directed Learning in Medical Schools: Making Students More Responsible. New Horizons, 11 (3).

32. Regan J.A. (2003). Motivating Students Towards Self-Directed Learning. Nurse Education Today, 23(8), 593-599.

33. Sampson J.P., Reardon R.C., Peterson G.W., Lenz J.G. (2004). Career Counselling and Services. Belmont, USA: Thomson Learning.

34. Savickas M.L. (1996). Handbook of Career Counselling Theory and Practice. Palo Alto, CA: Davies-Black Publishing.

35. Savickas M.L. (2005). The Theory and Practice of Career Construction. In S.D. Brown, R.W. Lent (Eds.), Career Development and Counselling: Putting Theory and Research to Work. Hoboken, NJ: Wiley, 42-70.

36. Self-Directed Learning: A Four-Step Process. (2016). Centre for Teaching Excellence. CA: University of Waterloo. Retrieved from https://uwaterloo.ca/centre-for-teaching-excellence/teachingresources/teaching-tips/tips-students/self-directed-learning/self-directed-learning-four-step-process

37. Soika I. (2017). Evolution of Dialogue for Students Career Guidance in Secondary Vocational Education. In V. Dislere (Ed.), The Proceedings of the International Scientific Conference Rural Environment, Education, Personality (REEP-2017), 10. Jelgava, Latvija: LLU, TF, 481-488. Retrieved from http://llufb.llu.lv/conference/REEP/2017/Latvia-Univ-Agricult-REEP-2017_proceedings-481-488.pdf

38. Smiles S. (1859). Self-Help. With Illustrations of Character and Conduct. London, UK: John Murray. Retrieved from https://archive.org/stream/selfhelpwithill00smilgoog\#page/n4/mode/2up

39. Smith T. (2017). Self-Directed Learning. Research Starters Education, 4(1), 1.

40. Super D.E. (1953). A Theory of Vocational Development. American Psychologist, 8, 185-190.

41. Super D.E. (1963). Self-Concepts in Vocational Development. In D. Super, R. Starishevsky, N. Matlin, J. Jordan (Eds.), Career Development: Self-Concept Theory. Princeton, NJ: The College Entrance Examination Board, 17-32.

42. Super D.E. (1983). Assessment in Career Guidance: Toward Truly Developmental Counselling. Personnel and Guidance Journal, 61(9), 555 - 562.

43. Tough A. (1979). The Adult's Learning Projects: A Fresh Approach to Theory and Practice in Adult Learning, $\left(2^{\text {nd }}\right.$ ed.). University Associates (Learning Concepts). Toronto, Ontario: San Diego and Ontario Institute for Studies in Education. 